\title{
Memória e Identidade Cristã nas Catacumbas Romanas (sécs. II-IV)
}

Orientador: André Luiz Rodrigues da Silva

Mestrando: Cristiano Luiz de França

Área de Concentração: Teologia Sistemático-Pastoral

Linha de Pesquisa: Fé e Cultura

Projeto de Pesquisa: Aplicação da metodologia patrística ao pensamento contemporâneo

Memória e a identidade são temas muito presentes nos debates e estudos contemporâneos, em muitos campos do conhecimento, abordados sob variados aspectos e envolvendo grupos diversificados. A perda de referências em meio às rápidas e profundas transformações que caracterizam o nosso tempo, certamente está relacionada com a necessidade de buscar compreender as causas e as consequências dessas mudanças. No campo religioso, este processo tem sido caracterizado pela perda progressiva das identidades herdadas, que tem como consequência problemas relacionados a transmissão de uma memória coletiva. Partindo desse contexto, esta pesquisa tem por finalidade refletir sobre as catacumbas cristãs, na cidade de Roma, entre os séculos II e IV, especialmente, enquanto lugar de memória e identidade para o Cristianismo, através de uma proposta de diálogo com outros campos do conhecimento, aos quais este tema se relaciona. Através dos registros deixados nestes cemitérios (iconográficos, epigráficos e outros), e de outros documentos, buscamos refletir sobre a importância das catacumbas cristãs para a preservação da memória e identidade do Cristianismo hoje. Em meio aos desafios advindos da pós-modernidade, intentamos que a reflexão em torno desses locais, como lugares de memória, possa contribuir para reflexões, a partir dos seus testemunhos, e inspirar opções e ações pastorais nas comunidades eclesiais.

Palavras-chave: Memória. Identidade Cristã. Catacumbas Romanas. 